\title{
Seasonal variation and source areas of airborne lead-210 at Ny-Ålesund in the High Arctic
}

\author{
Jussi Paatero, ${ }^{1}$ Murat Buyukay, ${ }^{1}$ Kim Holmén, ${ }^{2}$ Juha Hatakka' \& Yrjö Viisanen ${ }^{1}$ \\ 1 Finnish Meteorological Institute, PO Box 503, Fl-00101 Helsinki, Finland \\ 2 Norwegian Polar Institute, Fram Centre, NO-9296 Tromsø, Norway
}

\section{Keywords}

High Arctic; lead-210; Spitsbergen; trajectory analysis; troposphere.

\section{Correspondence}

Jussi Paatero, Finnish Meteorological Institute, PO Box 503, Fl-00101 Helsinki, Finland. E-mail: jussi.paatero@fmi.fi

doi:10.1111/j.1751-8369.2010.00185.x

\begin{abstract}
High-volume aerosol particle samples were collected onto glass-fibre filters at Mount Zeppelin Global Atmosphere Watch station, Ny-Ålesund, Svalbard, in 2001-05. The filters were assayed for lead-210 $\left({ }^{210} \mathrm{~Pb}\right)$ by measuring the alpha particles of its in-grown daughter nuclide polonium-210 $\left({ }^{210} \mathrm{Po}\right)$. The observed ${ }^{210} \mathrm{~Pb}$ activity concentrations at Mount Zeppelin vary between $<4$ and $1060 \mu \mathrm{Bq} \mathrm{m}{ }^{-3}$, with an arithmetic mean of $130 \mu \mathrm{Bq} \mathrm{m}{ }^{-3}$ and a median of $74 \mu \mathrm{Bq} \mathrm{m}{ }^{-3}$. The lowest ${ }^{210} \mathrm{~Pb}$ activity concentrations are found during summer and the highest are found in winter. This variation is caused by seasonal differences in the mixing conditions of the troposphere, the level of precipitation and the speed of atmospheric chemistry induced by solar radiation. The performed source area analysis, which is based on air mass back trajectories, indicated that in summer, ${ }^{210} \mathrm{~Pb}$ can be used as a tracer for air masses coming into contact with land areas within the past 5 days. In winter this cannot be performed because of the accumulation of ${ }^{210} \mathrm{~Pb}$-carrying aerosol particles into the Arctic atmosphere during the Arctic night. But even in winter a low ${ }^{210} \mathrm{~Pb}$ activity concentration indicates that the associated air mass has had little if any contact with land areas.
\end{abstract}

The Arctic region is experiencing environmental changes as a result of climate change and pressures by direct human activities, including air pollutants, as presented in the environmental assessment reports by the Arctic Climate Impact Assessment (Symon et al. 2005) and the Arctic Monitoring and Assessment Programme (AMAP 2002). The ice cover of the Arctic Ocean has decreased by $7 \%$ per decade during the last 30 years. This phenomenon has a huge impact on the albedo, and thus the atmospheric radiation balance in the area. In the continental Arctic regions the depth of the permafrost can extend to several hundreds of metres. During the summer season the uppermost $0.3-2.5 \mathrm{~m}$ of the soil melts. The depth of this active layer is increasing by almost $1 \mathrm{~cm}$ per year owing to the warming climate. The melting of the permafrost will cause dramatic changes to the environment. For example, lakes can dry out, bogs producing peat can turn into ponds, and methane and carbon dioxide fluxes between the soil and the atmosphere can increase. All these phenomena can change the large-scale atmospheric flow patterns affecting the transport of airborne pollutants, including radionuclides, to the Arctic.

Lead-210 $\left({ }^{210} \mathrm{~Pb}\right)$ is formed in the atmosphere from the radioactive noble gas radon-222 $\left({ }^{222} \mathrm{Rn}\right)$ emanating from the Earth's crust. Of the airborne ${ }^{222} \mathrm{Rn}, 99 \%$ originates from land and only $1 \%$ originates from the sea (Baskaran et al. 1993). In the air, ${ }^{222} \mathrm{Rn}$, being a noble gas, exists as single atoms. Its progeny, including lead-210, are, however, heavy metal atoms, and are rapidly attached to ambient aerosol particles. Most of the airborne ${ }^{210} \mathrm{~Pb}$ activity is attached to accumulation-mode aerosol particles with an aerodynamic diameter of a few hundred nanometres (Sanak et al. 1981; Papastefanou \& Bondietti 1991; Suzuki et al. 1996; Suzuki et al. 1999). Owing to its long half-life (22 years), ${ }^{210} \mathrm{~Pb}$ is removed from the atmosphere by the various scavenging processes, especially wet deposition, of aerosol particles carrying it rather than its radioactive decay. The amount of ${ }^{210} \mathrm{~Pb}$ in the air is not affected by anthropogenic activities (Hötzl \& Winkler 1987). Mean aerosol residence times can be calculated from the activity ratio of ${ }^{210} \mathrm{~Pb}$ and its progeny, 
bismuth-210 $\left({ }^{210} \mathrm{Bi}\right)$ or polonium-210 $\left({ }^{210} \mathrm{Po}\right)$ (Papastefanou \& Bondietti 1991). The observed residence times vary between 0 days and over 5 weeks. Generally there is a tendency towards longer residence times with decreasing temperature (Mattsson 1975; Samuelsson et al. 1986; Baskaran \& Shaw 2001). The practically exclusive formation mechanism of airborne ${ }^{210} \mathrm{~Pb}$ facilitates its use as a tracer for air masses with a recent contact to land areas (Preiss et al. 1996). The Comprehensive Test Ban Treaty Organization gathers information about the ${ }^{210} \mathrm{~Pb}$ as well as beryllium-7 ( $\left.{ }^{7} \mathrm{Be}\right)$ activity content of the ground-level air around the globe as a side product to nuclear test monitoring.

In this project we have measured the activity concentration of ${ }^{210} \mathrm{~Pb}$ in the air at the Mount Zeppelin Global Atmosphere Watch (GAW) station. The GAW programme is coordinated by the World Meteorological Organization. The GAW monitoring programme includes a co-ordinated global network of some 20 observing stations, and it provides data for scientific assessments and for early warnings of changes in the chemical composition and related physical characteristics of the atmosphere. GAW monitors, among other things, greenhouse gases, ozone and ultraviolet radiation, certain reactive gases and aerosol particles. The data obtained in this study during the 5-year period 2001-05 can be used as a tracer to help identify variations in transport behaviour of air masses, and therefore also of air pollutants, in the Arctic region.

\section{Materials and methods}

The sampling site was at Mount Zeppelin GAW station, Ny-Ålesund, $\left(78^{\circ} 58^{\prime} \mathrm{N}, 11^{\circ} 53^{\prime} \mathrm{E}\right)$, on the western coast of Spitssbergen, the largest island in the Svalbard archipelago (Paatero \& Holmen 2004). The station is located $474 \mathrm{~m}$ a.s.l. (Fig. 1).

High-volume aerosol particle samples were collected onto glass-fibre filters (Munktell, Falun Sweden). The sampler is made of stainless steel. The flow rate was ca. $120 \mathrm{~m}^{3} \mathrm{~h}^{-1}$, and was measured with a pressure difference gauge over a throat. Three samples per week were collected with filter changes on Mondays, Wednesdays and Fridays. One of the 25 filters was left unexposed, and was used as a field blank sample. All the filters, both samples and field blanks, were stored in cardboard boxes at room temperature $\left(\mathrm{ca} .20^{\circ} \mathrm{C}\right.$ ) before measurement. The indoor ${ }^{222} \mathrm{Rn}$ diffusing into the filters during storage has not been found to have a discernible effect on the ${ }^{210} \mathrm{~Pb}$ content of the filters (Paatero et al. 2005).

The measurement of ${ }^{210} \mathrm{~Pb}$ content of the aerosol filters is based on the alpha counting of the in-grown daughter nuclide ${ }^{210} \mathrm{Po}$. The exposed filters and the field blanks were assayed for ${ }^{210} \mathrm{~Pb} 6$ months after sampling with an

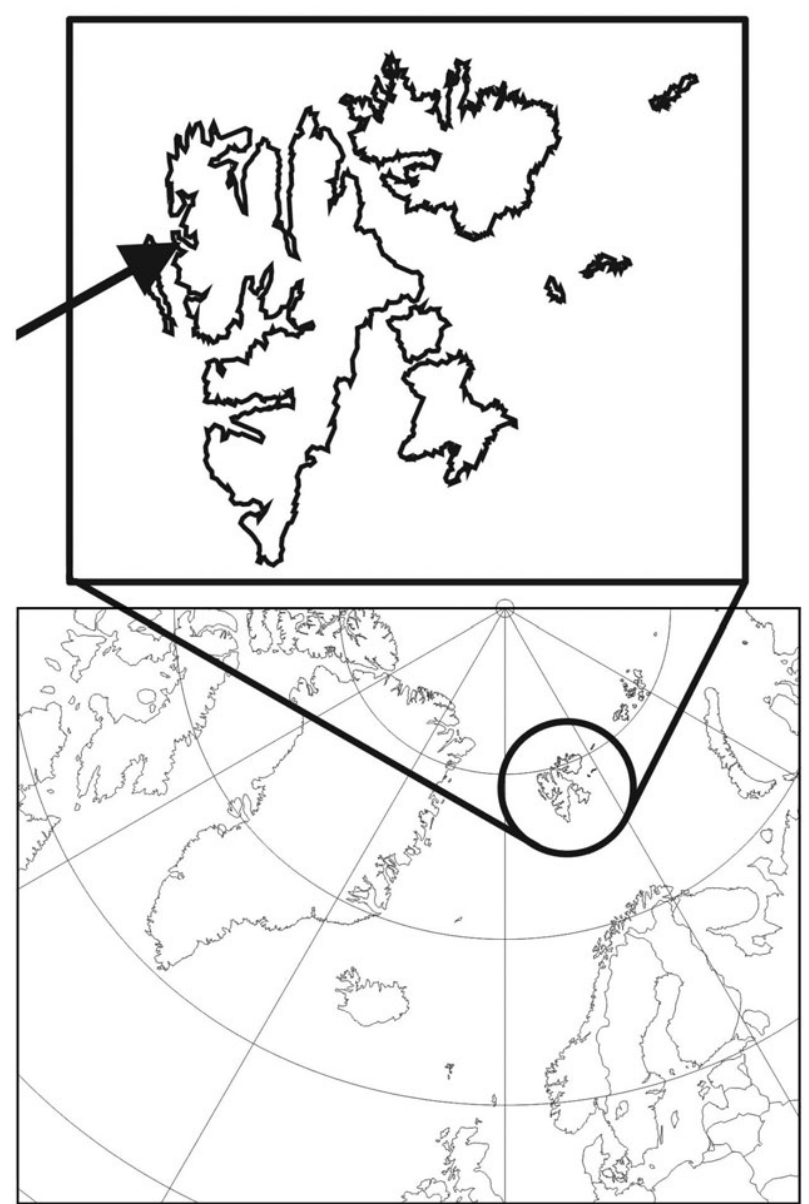

Fig. 1 Location of the sampling site, Mount Zeppelin Global Atmosphere Watch station, Ny-Ålesund, Svalbard.

automatic alpha/beta analyser. The technical details of the instrument were described in Mattsson et al. (1996). The detector arrangement consists of five gas-flow proportional counters. The flow gas is P-10, a mixture of argon $(90 \%)$ and methane $(10 \%)$. The effective window area is $625 \mathrm{~cm}^{2}$. The counter immediately above the filter has a thin plastic window and measures alpha particles. The alpha counting efficiency is $41.5 \%$. The other four counters are for beta particle counting and for anticoincidence background suppression.

The results were handled as follows. First the alpha count rate of the field blank was subtracted from the sample alpha count rate. In most cases the field blank did not deviate from the instrumental background. Next, a fixed value of $0.5 \mathrm{cpm}$ was subtracted from the alpha count rate to take into consideration the ${ }^{210} \mathrm{Po}$ already on the filter at the end of sampling. The alpha count rate was converted to ${ }^{210} \mathrm{Po}$ activity by dividing it with the counting efficiency. Then the ${ }^{210} \mathrm{~Pb}$ activity at the end of sampling was calculated from the delay time between the sampling 
Fig. 2 Airborne ${ }^{210} \mathrm{~Pb}\left(\mu \mathrm{Bq} \mathrm{m} \mathrm{m}^{-3}\right)$ at Mount Zeppelin Global Atmosphere Watch station, Svalbard, 2001-05. The sampler was broken from May to December 2004.

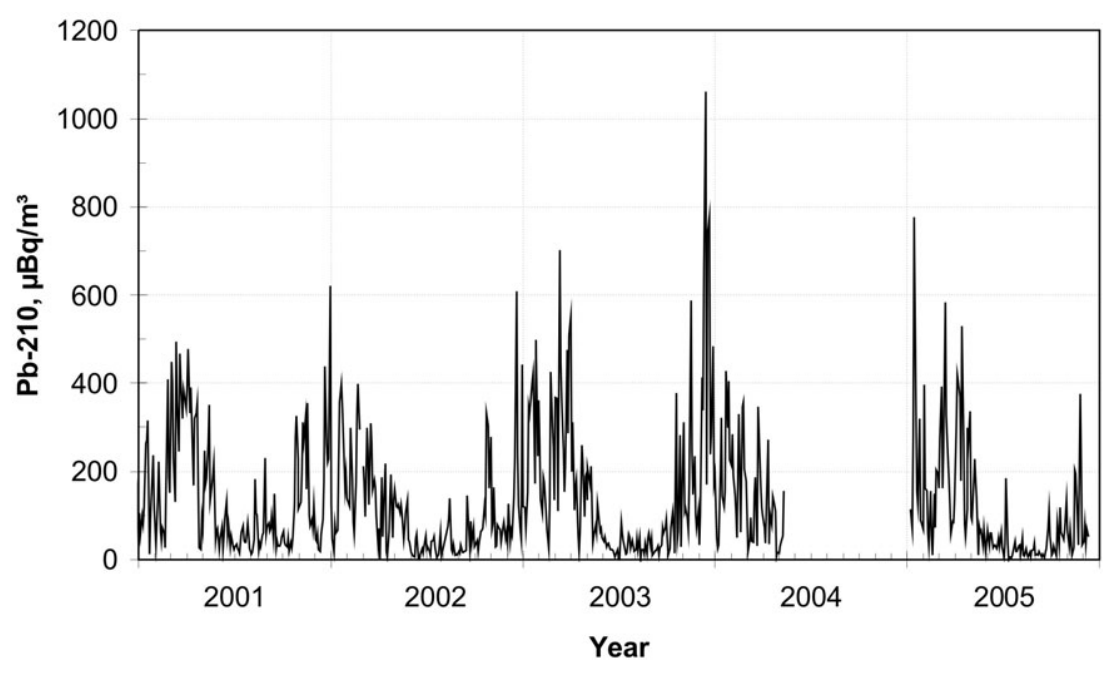

and the measurement, and from the in-grown ${ }^{210} \mathrm{Po}$ activity. Finally, the ${ }^{210} \mathrm{~Pb}$ activity was divided by the air volume of the sample to obtain an activity concentration. The method can lead to an overestimation of the ${ }^{210} \mathrm{~Pb}$ activity concentration because of the uncertainty related to the level of ${ }^{210} \mathrm{Po}$ already present on the filter at the end of sampling. This overestimation is expected to be, even in the worst case, less than $20 \%$. The ${ }^{210} \mathrm{Po} /{ }^{210} \mathrm{~Pb}$ activity ratio is at its seasonal maximum in late winter because of the long residence time of aerosol particles in the air, allowing time for ${ }^{210} \mathrm{Po}$ to accumulate. The effect of unsupported ${ }^{210} \mathrm{Po}$ in the air is expected to be a rare incident related to atmospheric long-range transport from volcano eruptions or biomass burning events (Stohl et al. 2007; Paatero et al. 2009).

To check the stability of the instrument, reference samples (plutonium-242 [ $\left.{ }^{242} \mathrm{Pu}\right]$, strontium-90 [ $\left.{ }^{90} \mathrm{Sr}\right]$ and iron-55 $\left.\left[{ }^{55} \mathrm{Fe}\right]\right)$ are measured daily. The measurement uncertainty depends on the level of ${ }^{210} \mathrm{~Pb}$ present on the filter and counting time. Usually the $1 \sigma$ standard deviation of the radioassay varies between 5 and $10 \%$, but can be significantly larger if the activity on the filter is very low.

\section{Results and discussion}

Altogether 666 aerosol filter samples were collected at the Mount Zeppelin GAW station in 2001-05. The observed ${ }^{210} \mathrm{~Pb}$ activity concentrations varied between $<4$ and $1060 \mu \mathrm{Bq} \mathrm{m}{ }^{-3}$. The median, arithmetic mean and geometric mean activity concentrations were 74,130 and $74 \mu \mathrm{Bq} \mathrm{m}^{-3}$, respectively. The $10,25,75$ and $90 \%$ percentiles were 16, 33, 180 and $330 \mu \mathrm{Bq} \mathrm{m}^{-3}$, respectively. Suzuki et al. (1996) reported ${ }^{210} \mathrm{~Pb}$ activity concentrations ranging from 83 to $1204 \mu \mathrm{Bq} \mathrm{m}^{-3}$, and an average concentration of $325 \mu \mathrm{Bq} \mathrm{m}^{-3}$ at Ny-Ålesund in FebruaryMarch 1995.

Samuelsson et al. (1986) reported an average concentration of $75 \mu \mathrm{Bq} \mathrm{m}^{-3}$ during a Swedish ice-breaker expedition in July-September 1980 between $75^{\circ}$ and $83^{\circ} \mathrm{N}$, and between Greenland and Franz Josef Land. Mysłek-Laurikainen et al. (2006) reported that the ${ }^{210} \mathrm{~Pb}$ activity concentration in the air at the Polish research station at Hornsund, some $200 \mathrm{~km}$ south of Ny-Ålesund, varied between 0 and $1200 \mu \mathrm{Bq} \mathrm{m}^{-3}$. The values found at Svalbard are very low compared with continental areas, but are clearly higher than in Antarctic areas. For example, the average and maximum monthly ${ }^{210} \mathrm{~Pb}$ activity concentrations in Belgrade, former Yugoslavia, were 1200 and $3170 \mu \mathrm{Bq} \mathrm{m}^{-3}$, respectively (Todorovic et al. 2000). At Marambio research station $\left(64^{\circ} 14^{\prime} \mathrm{S}, 56^{\circ} 43^{\prime} \mathrm{W}\right)$, close to the Antarctic Peninsula, the mean annual ${ }^{210} \mathrm{~Pb}$ activity concentration was only $4.5 \mu \mathrm{Bq} \mathrm{m}^{-3}$ in 2005 (Paatero et al. 2007).

The contribution of Svalbard itself as a source of airborne ${ }^{210} \mathrm{~Pb}$ is likely to be very small because of the associated time scales. The area of the islands is only $63000 \mathrm{~km}^{2}$, and $60 \%$ of it is covered with glaciers, with a negligible radon exhalation potential. An air mass travelling from east over the islands with a speed of, e.g., $4 \mathrm{~m} \mathrm{~s}^{-1}$ would spend only about $12 \mathrm{~h}$ above ground before arriving at the west coast of Svalbard. The radon accumulated into the air would, on average, still have 5 days left before decaying into ${ }^{210} \mathrm{~Pb}$. During these 5 days the air mass would have moved $1700 \mathrm{~km}$ away from Svalbard.

The observed ${ }^{210} \mathrm{~Pb}$ activity concentrations present a clear seasonal variation, with highest concentrations in winter (Fig. 2; Table 1). This is attributed to the small 
Table 1 Average monthly activity concentration of ${ }^{210} \mathrm{~Pb}$ in the air $\left(\mu \mathrm{Bq} \mathrm{m}^{-3}\right)$, measured at the Mount Zeppelin Global Atmosphere Watch station, Svalbard, 2001-05.

\begin{tabular}{lll}
\hline & & \\
\cline { 2 - 3 } Month & Average & Standard error of mean \\
\hline Jan. & 202 & 18 \\
Feb. & 169 & 15 \\
Mar. & 237 & 19 \\
Apr. & 184 & 18 \\
May & 112 & 9 \\
Jun. & 37 & 4 \\
Jul. & 33 & 4 \\
Aug. & 42 & 7 \\
Sep. & 44 & 5 \\
Oct. & 93 & 13 \\
Nov. & 136 & 16 \\
Dec. & 229 & 37 \\
\hline
\end{tabular}

level of precipitation, reduced air chemistry and stagnant mixing conditions in the troposphere during the Arctic night. These factors increase the aerosol residence time, and thus the accumulation of ${ }^{210} \mathrm{~Pb}$ in the air. The phenomenon is similar to Arctic haze, the accumulation of soot and sulphate particles in the Arctic atmosphere during winter (e.g., Shaw 1983). The maximum concentrations are only moderately lower in the High Arctic compared with Finland. For example, in northern Finland the average January to March activity concentration was about $280 \mu \mathrm{Bq} \mathrm{m}{ }^{-3}$, and in southern Finland $300 \mu \mathrm{Bq} \mathrm{m}{ }^{-3}$ in 1995-97 (Paatero \& Hatakka 2002).

The minimum ${ }^{210} \mathrm{~Pb}$ activity concentrations occur in the High Arctic in summer, when the continuous solar radiation induces efficient vertical mixing of the troposphere. At the same time, the level of precipitation, which causes wet deposition and atmospheric chemistry induced by solar radiation, are at their seasonal maximum. This is in agreement with observations in Finland. For example, in northern Finland the average May to July activity concentration was about $140 \mu \mathrm{Bq} \mathrm{m}^{-3}$, and in southern Finland $200 \mu \mathrm{Bq} \mathrm{m}^{-3}$ in 1995-97 (Paatero \& Hatakka 2002). However, the concentrations are even lower in the High Arctic. In southern Germany the seasonal variation is much less profound than in Svalbard, even though the monthly mean concentrations in southern Germany are much higher: $400-700 \mu \mathrm{Bq} \mathrm{m}^{-3}$ (Winkler \& Rosner 2000)

To analyse the ${ }^{210} \mathrm{~Pb}$ observations at Mount Zeppelin, a set of three-dimensional 5-day air mass back trajectories were calculated using the trajectory model FLEXTRA (Stohl \& Seibert 1998). The wind fields were obtained from the European Centre for Medium-Range Weather Forecasts. The trajectories were utilized by two different methods. Figure 3 depicts the starting points of trajecto- ries coincident with the lowest $5 \%$ of the ${ }^{210} \mathrm{~Pb}$ activity concentrations: $<10 \mu \mathrm{Bq} \mathrm{m}{ }^{-3}$. Five days earlier, most of the air masses with a low ${ }^{210} \mathrm{~Pb}$ content were situated over the Arctic Ocean, the North Atlantic Ocean or Greenland. Only a few starting points are over northern Europe or the coastal regions of Siberia. On the other hand, most of the trajectory starting points coincident with the highest $5 \%$ of ${ }^{210} \mathrm{~Pb}$ activity concentrations, $>400 \mu \mathrm{Bq} \mathrm{m}^{-3}$, are located over Siberia (Fig. 4). A number of starting points are located between the Bering Strait and the North Pole, contrary to preliminary expectations. This kind of analysis does not, of course, take into account curvatures that the air masses make over the oceans or continents. It is therefore not a proof for particular types of air masses, either continental or maritime. But it gives a general picture of source areas of air masses with high or low activity concentrations of ${ }^{210} \mathrm{~Pb}$ in the air. The uncertainty related to air mass trajectory calculations has been reviewed by Stohl (1998).

Secondly, a statistical evaluation of the ${ }^{210} \mathrm{~Pb}$ activity concentrations in different air masses was performed. The 120 hourly locations of each trajectory arriving at Mount Zeppelin were combined with the ${ }^{210} \mathrm{~Pb}$ activity concentrations observed during the moment of arrival. Next, the concentration-location pairs of all the chosen trajectories were averaged over cells of $1^{\circ}$ latitude and $1^{\circ}$ longitude. The cell in which Mount Zeppelin is situated thereby obtains a value close to the average concentration. The activity concentrations obtained in the cells should not be interpreted as absolute concentration values, but rather as concentrations relative to the average concentration. The statistical accuracy decreases with increasing distance from the sampling site, as the averaged area contains fewer and fewer concentration-location pairs. A similar method, but with certain statistical enhancements, has been used previously at the Finnish Meteorological Institute to identify the sources of airborne substances, e.g., atmospheric fine particles and sulphur dioxide, ${ }^{210} \mathrm{~Pb}$ and ${ }^{7}$ Be in Finnish Lapland (Virkkula et al. 1995; Virkkula et al. 1997; Paatero \& Hatakka 2000). Two subsets of trajectories and ${ }^{210} \mathrm{~Pb}$ observations were used in the subsequent analyses: summer months (June-September) and winter months (October-April). These periods were chosen on the basis of the seasonal variation of ${ }^{210} \mathrm{~Pb}$ activity concentration in Fig. 2 .

The trajectory analysis of summertime source areas of airborne ${ }^{210} \mathrm{~Pb}$ in Svalbard is presented in Fig. 5. The highest ${ }^{210} \mathrm{~Pb}$ activity concentrations are found in air masses coming from northern Europe and the northwestern coastal region of Russia. Somewhat elevated concentrations are associated with air masses coming from Arctic Canada, too. The lowest concentrations are found in air masses coming from Greenland, the North 
Fig. 3 Starting points (open red squares) of the 5-day-long air mass back trajectories coincident with the lowest $5 \%$ of the ${ }^{210} \mathrm{~Pb}$ activity concentrations, $<10 \mu \mathrm{Bq} \mathrm{m}^{-3}$, at Mount Zeppelin Global Atmosphere Watch station (solid black square).

Fig. 4 Starting points (open red squares) of the 5-day-long air mass back trajectories coincident with the highest $5 \%$ of the ${ }^{210} \mathrm{~Pb}$ activity concentrations, $>400 \mu \mathrm{Bq} \mathrm{m}^{-3}$, at Mount Zeppelin Global Atmosphere Watch station (solid black square).
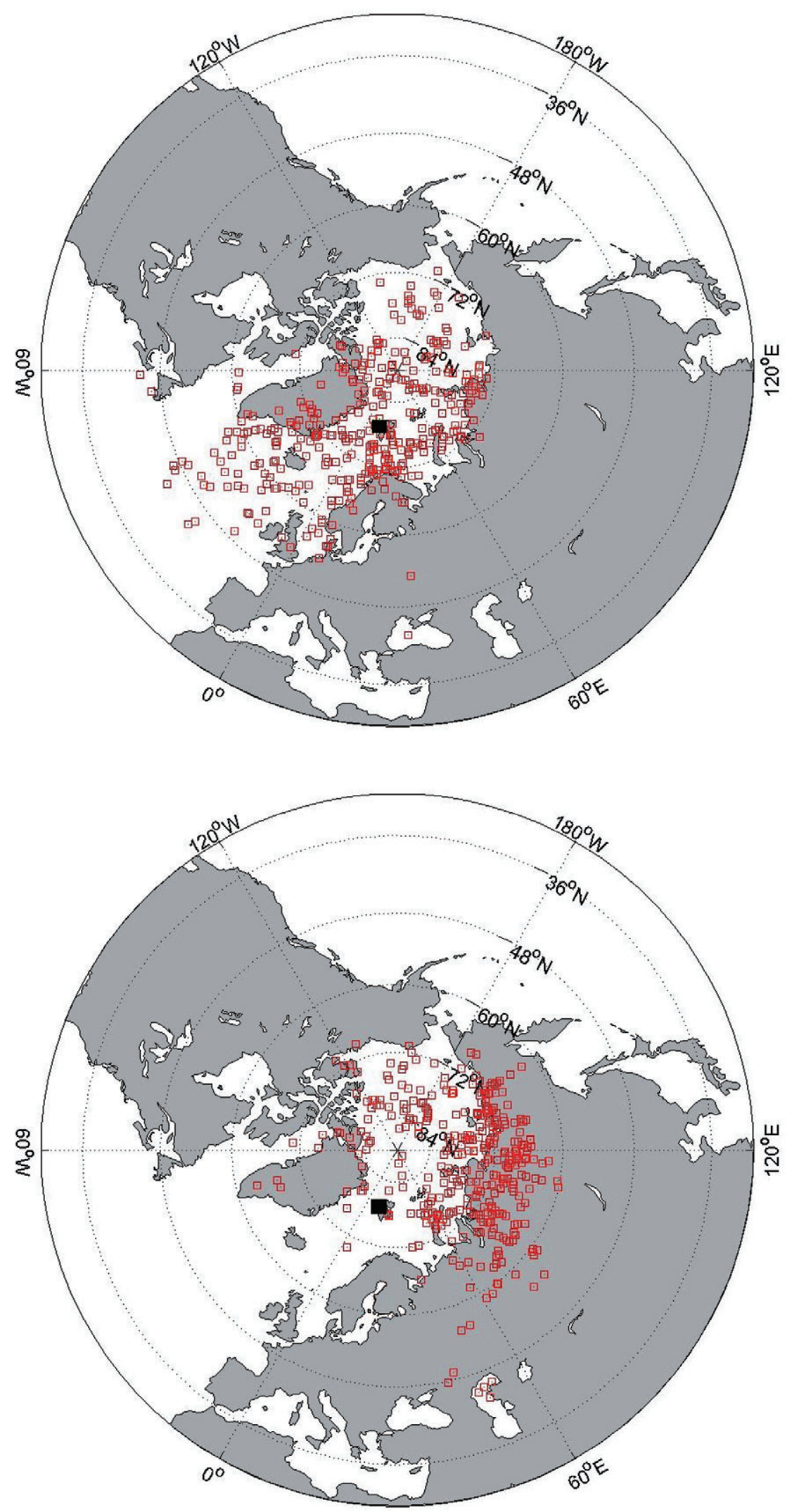

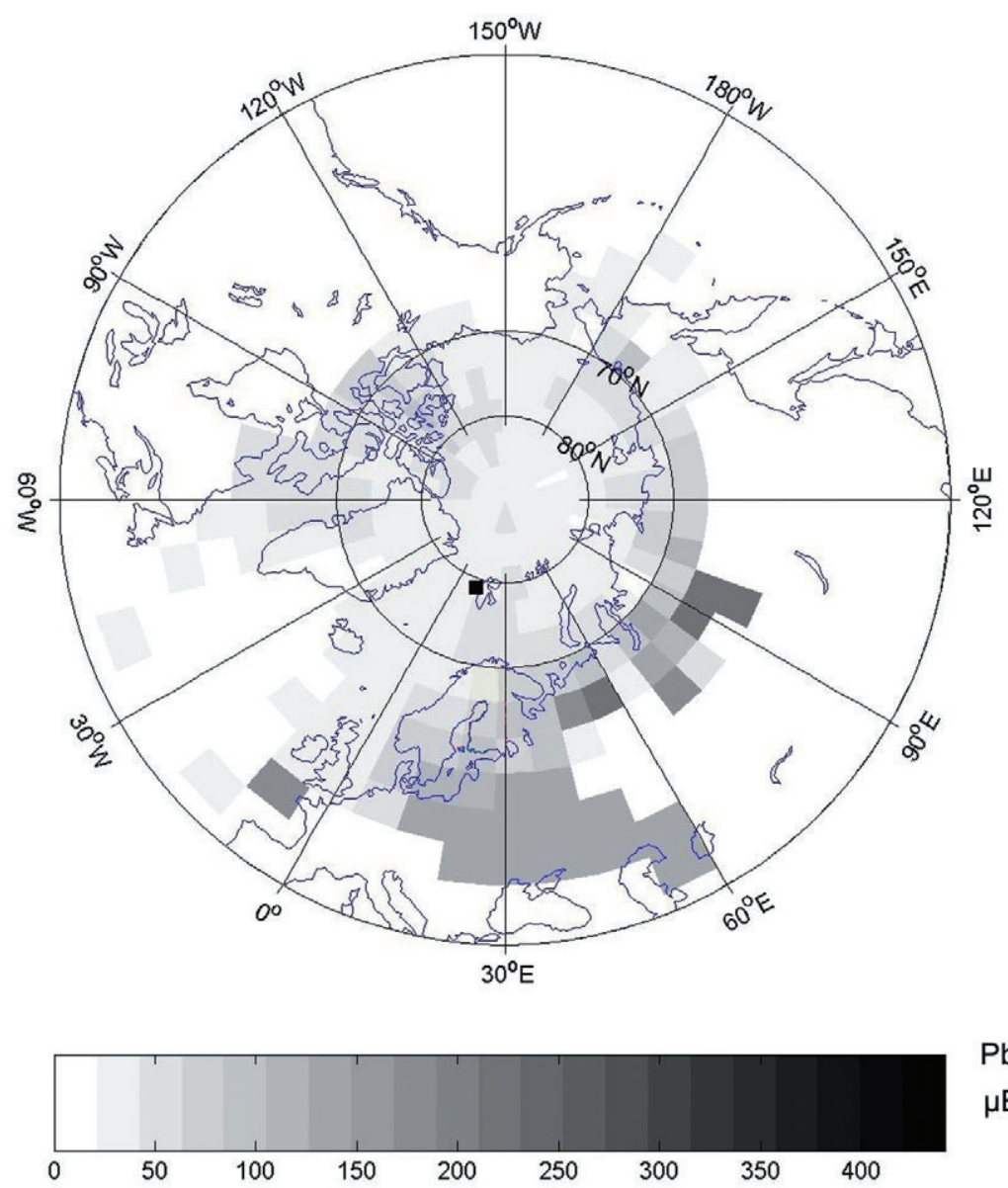

$\mathrm{Pb}-210$, $\mu \mathrm{Bq} / \mathrm{m}^{3}$

Fig. 5 Source areas of airborne ${ }^{210} \mathrm{~Pb}$ $\left(\mu \mathrm{Bq} \mathrm{m} \mathrm{m}^{-3}\right)$ at Mount Zeppelin Global Atmosphere Watch station (solid black square), from June to September 2001-05.
Atlantic Ocean and the Central Arctic Ocean. This is in agreement with the classical view that airborne ${ }^{210} \mathrm{~Pb}$ is a tracer for recent contact of air masses with land areas. In winter, the highest ${ }^{210} \mathrm{~Pb}$ activity concentrations are found in air masses coming from Russia, Alaska and Arctic Canada (Fig. 6). High concentrations are also associated with air masses coming from the Arctic Ocean between Alaska, north-eastern Siberia and the North Pole. Air masses containing slightly elevated ${ }^{210} \mathrm{~Pb}$ activity concentrations arrive in Svalbard from northern Europe and Greenland. The lowest concentrations are found in air masses coming from the North Atlantic Ocean.

The accumulation of ${ }^{210} \mathrm{~Pb}$-carrying aerosol particles into the Arctic atmosphere during winter explains why the Arctic Ocean apparently is a source area of ${ }^{210} \mathrm{~Pb}$. An interesting detail is the area of lower ${ }^{210} \mathrm{~Pb}$ activity concentrations between Norway and Iceland, and the region immediately north-west of Norway. This phenomenon can be attributed to the Gulf Stream going northwards along the coast of Norway. This warm sea current seems to cause enough convection in the air aloft that airborne ${ }^{210} \mathrm{~Pb}$ is diluted to a bigger air volume.

\section{Conclusions}

In this report we have presented a 5-year observation series of airborne ${ }^{210} \mathrm{~Pb}$ at Mount Zeppelin GAW station. To the best of our knowledge this is the longest data set on airborne ${ }^{210} \mathrm{~Pb}$ in the High Arctic. In winter the ${ }^{210} \mathrm{~Pb}$ activity concentrations found in Svalbard are comparable with those found in Finland. In summer, however, the concentrations are much lower than in continental areas. The performed source area analysis, which is based on air mass back trajectories, indicated that in summer ${ }^{210} \mathrm{~Pb}$ can be used as a tracer for air masses having been in contact with land areas within the past 5 days. In winter this cannot be used because of the accumulation of ${ }^{210} \mathrm{~Pb}$ carrying aerosol particles in the Arctic atmosphere during the Arctic night. But even in winter a low ${ }^{210} \mathrm{~Pb}$ activity concentration indicates that the associated air mass has had little if any contact with land areas.

Airborne ${ }^{210} \mathrm{~Pb}$ has been used in verifications of atmospheric general circulation models (Feichter et al. 1991). The data produced in this study might find use in verification activities, as there are few data sets on airborne 


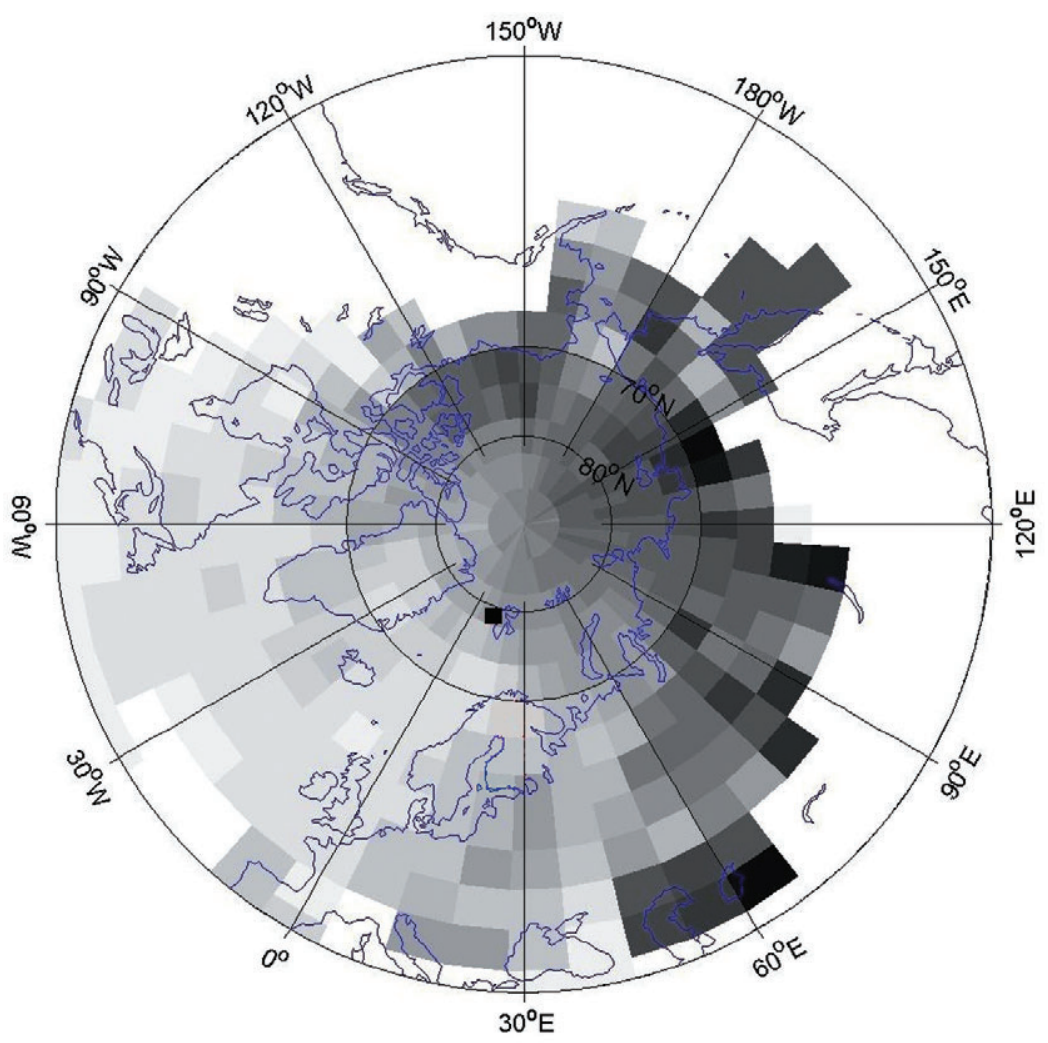

Fig. 6 Source areas of airborne ${ }^{210} \mathrm{~Pb}$ $\left(\mu \mathrm{Bq} \mathrm{m}{ }^{-3}\right)$ at Mount Zeppelin Global Atmosphere Watch station (small solid black square), from December to April 2001-05.

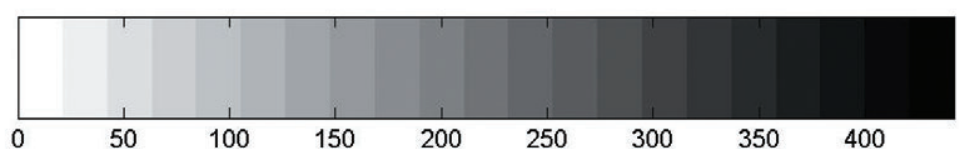

$\mathrm{Pb}-210$, $\mu \mathrm{Bq} / \mathrm{m}^{3}$

${ }^{210} \mathrm{~Pb}$ available from $79^{\circ} \mathrm{N}$. As a contribution to the International Polar Year 2007-08, the recent filters have now also been measured for ${ }^{7} \mathrm{Be}$.

\section{Acknowledgements}

This work was started with the financial support of the Enhancing Access to Research Infrastructure Action of the European Commission's Human Potential Programme. The authors are also indebted to the station engineers of the Mount Zeppelin GAW station for taking care of the sampling programme, to Kings Bay AS for logistical support, and to Ms M. Laaksonen for the laboratory measurements and preliminary data handling.

\section{References}

AMAP (Arctic Monitoring and Assessment Programme) 2002. Arctic pollution 2002. Oslo: Arctic Monitoring and Assessment Programme.

Baskaran M., Coleman C.H. \& Santschi P.H. 1993. Atmospheric depositional fluxes of ${ }^{7} \mathrm{Be}$ and ${ }^{210} \mathrm{~Pb}$ at
Galveston and College Station, Texas. Journal of Geophysical Research-Atmospheres 98, 20 555-20 571.

Baskaran M. \& Shaw G.E. 2001. Residence time of Arctic haze aerosols using the concentrations and activity ratios of ${ }^{210} \mathrm{Po},{ }^{210} \mathrm{~Pb}$ and ${ }^{7} \mathrm{Be}$. Journal of Aerosol Science 32, 443-452.

Feichter J., Brost R.A. \& Heimann M. 1991. Three-dimensional modeling of the concentration and deposition of ${ }^{210} \mathrm{~Pb}$ aerosols. Journal of Geophysical Research-Atmospheres 96, 22 447-22 460.

Hötzl H. \& Winkler R. 1987. Activity concentrations of ${ }^{226} \mathrm{Ra}$, ${ }^{228} \mathrm{Ra},{ }^{210} \mathrm{~Pb},{ }^{40} \mathrm{~K}$ and ${ }^{7} \mathrm{Be}$ and their temporal variations in surface air. Journal of Environmental Radioactivity 5 , 445-458.

Mattsson R. 1975. Measurements of ${ }^{210} \mathrm{~Pb},{ }^{210} \mathrm{Bi}$ and ${ }^{210} \mathrm{Po}$ in urban and rural air in Finland. Contributions no. 81. Helsinki: Finnish Meteorological Institute.

Mattsson R., Paatero J. \& Hatakka J. 1996. Automatic alpha/ beta analyser for air filter samples-absolute determination of radon progeny by pseudo-coincidence techniques. Radiation Protection Dosimetry 63, 133-139.

Mysłek-Laurikainen B., Matul M., Mikołajewski S., Trzaskowska H., Preibisz Z., Garanty I., Kubicki M., 
Rakowski P., Krynicki T. \& Stefański M. 2006. Air aerosol sampling station AZA-1000 at Polish Polar Station in Hornsund, Spitsbergen. Nukleonika 51, 137-140.

Paatero J., Buyukay M., Aaltonen V., Garcia M.J., Sanchéz R., Hatakka J., Virkkula A. \& Teinilä K. 2007. Airborne lead-210 at research stations Aboa and Marambio, Antarctic. In A.S. Paschoa et al. (eds.): Book of abstracts of the 8th International Symposium on the Natural Radiation Environment (NRE-VIII), Búzios, Rio de Janeiro, 7-12 October 2007. Pp. 65. Rio de Janeiro: Natural Radiation Environment Association.

Paatero J. \& Hatakka J. 2000. Source areas of airborne ${ }^{7} \mathrm{Be}$ and ${ }^{210} \mathrm{~Pb}$ measured in northern Finland. Health Physics 79 , 691-696.

Paatero J. \& Hatakka J. 2002. Observations of long-lived airborne and deposited radioactivity in Finland 1995-1997. Publications on Air Quality no. 30. Helsinki: Finnish Meteorological Institute.

Paatero J., Hatakka J., Ikäheimonen T.K., Klemola S., Salminen S. \& Lehto J. 2005. Analysis intercomparison of lead-210 in aerosol filters. In: Radiological protection in transition. SSI Rapport 2005:15. Pp. 55. Stockholm: Swedish Radiation Protection Authority.

Paatero J. \& Holmén K. (eds.) 2004. The First Ny-ÅlesundPallas-Sodankylä Atmospheric Research Workshop, Pallas, Finland 1-3 March 2004. Extended abstracts. Reports 2004: 7. Helsinki: Finnish Meteorological Institute.

Paatero J., Vesterbacka K., Makkonen U., Kyllönen K., Hellén H., Hatakka J. \& Anttila P. 2009. Resuspension of radionuclides into the atmosphere due to forest fires. Journal of Radioanalytical and Nuclear Chemistry 282, 473-476.

Papastefanou C. \& Bondietti E.A. 1991. Mean residence times of atmospheric aerosols in the boundary layer as determined from ${ }^{210} \mathrm{Bi} /{ }^{210} \mathrm{~Pb}$ activity ratios. Journal of Aerosol Science 22, 927-931.

Preiss N., Mélières M.-A. \& Pourchet M. 1996. A compilation of data on lead 210 concentration in surface air and fluxes at the air-surface and water-sediment interfaces. Journal of Geophysical Research-Atmospheres 101, 28 847-28 862.

Samuelsson C., Hallstadius L., Persson B., Hedvall R., Holm E. \& Forkman B. $1986 .{ }^{222} \mathrm{Rn}$ and ${ }^{210} \mathrm{~Pb}$ in the Arctic summer air. Journal of Environmental Radioactivity 3, 35-54.
Sanak J., Gaudry A. \& Lambert G. 1981. Size distribution of ${ }^{210} \mathrm{~Pb}$ aerosols over oceans. Geophysical Research Letters 8, 1067-1069.

Shaw G.E. 1983. Evidence for a central Eurasian source area of Arctic haze in Alaska. Nature 299, 815-818.

Stohl A. 1998. Computation, accuracy and applications of trajectories-a review and bibliography. Atmospheric Environment 32, 947-966.

Stohl A., Berg T., Burkhart J. F., Fjaeraa A.M., Forster C., Herber A., Hov O., Lunder C., McMillan W.W., Oltmans S., Shiobara M., Simpson D., Solberg S., Stebel K., Strom J., Torseth K., Treffeisen R., Virkkunen K. \& Yttri K.E. 2007. Arctic smoke-record high air pollution levels in the European Arctic due to agricultural fires in eastern Europe in spring 2006. Atmospheric Chemistry and Physics 7, 511-534.

Stohl A. \& Seibert P. 1998. Accuracy of trajectories as determined from the conservation of meteorological tracers. Quarterly Journal of the Royal Meteorological Society 124, 1465-1484.

Suzuki T., Maruyama Y., Nakayama N., Yamada K. \& Ohta K. 1999. Measurement of the ${ }^{210} \mathrm{Po} /{ }^{210} \mathrm{~Pb}$ activity ratio in size fractionated aerosols from the coast of the Japan Sea. Atmospheric Environment 33, 2285-2288.

Suzuki T., Nakayama N., Igarashi M., Kamiyama K. \& Watanabe O. 1996. Concentrations of ${ }^{210} \mathrm{~Pb}$ and ${ }^{210} \mathrm{Po}$ in the atmosphere of Ny-Ålesund. Svalbard. Memoirs of National Institute of Polar Research 51, 233-237.

Symon C., Arris L. \& Heal B. (eds.) 2005. Arctic climate impact assessment. Cambridge: Cambridge University Press.

Todorovic D., Popovic D., Djuric G. \& Radenkovic M. 2000. ${ }^{210} \mathrm{~Pb}$ in ground-level air in the Belgrade city area. Atmospheric Environment 34, 3245-3248.

Virkkula A., Hillamo R.E., Kerminen V.-M. \& Stohl A. 1997. The influence of Kola Peninsula, continental European and marine sources on the number concentrations and scattering coefficients of the atmospheric aerosol in Finnish Lapland. Boreal Environment Research 2, 317-336.

Virkkula A., Mäkinen M., Hillamo R. \& Stohl A. 1995. Atmospheric aerosol in the Finnish Arctic: particle number concentrations, chemical characteristics, and source analysis. Water, Air, e Soil Pollution 85, 1997-2002.

Winkler R. \& Rosner G. 2000. Seasonal and long-term variation of ${ }^{210} \mathrm{~Pb}$ concentration in air, atmospheric deposition rate and total deposition velocity in south Germany. Science of the Total Environment 263, 57-68. 